\title{
Peroxisome Proliferator-Activated Receptor $\alpha$ Agonists Differentially Regulate Inhibitor of DNA Binding Expression in Rodents and Human Cells
}

\author{
María del Carmen González, ${ }^{1}$ J. Christopher Corton, ${ }^{2}$ Nuria Acero, ${ }^{1}$ \\ Dolores Muñoz-Mingarro, ${ }^{1}$ Yolanda Quirós, ${ }^{3}$ Juan José Álvarez-Millán, ${ }^{3}$ \\ Emilio Herrera, ${ }^{1}$ and Carlos Bocos ${ }^{1}$ \\ ${ }^{1}$ Departmento de Biología, Facultades de Farmacia y Medicina, Universidad San Pablo-CEU, Urbanización Montepríncipe, \\ Boadilla del Monte, 28668 Madrid, Spain \\ ${ }^{2}$ Integrated Systems Toxicology Division, National Health and Environmental Effects Research Lab, US Environmental \\ Protection Agency, 109 T.W. Alexander Drive, Research Triangle Park, NC 27711, USA \\ ${ }^{3}$ Consulting Quimico Sanitario (CQS) Laboratory, 28020 Madrid, Spain
}

Correspondence should be addressed to Carlos Bocos, carbocos@ceu.es

Received 9 February 2012; Revised 2 April 2012; Accepted 4 April 2012

Academic Editor: Yuji Kamijo

Copyright ( $) 2012$ María del Carmen González et al. This is an open access article distributed under the Creative Commons Attribution License, which permits unrestricted use, distribution, and reproduction in any medium, provided the original work is properly cited.

\begin{abstract}
Inhibitor of DNA binding (Id2) is a helix-loop-helix (HLH) transcription factor that participates in cell differentiation and proliferation. Id 2 has been linked to the development of cardiovascular diseases since thiazolidinediones, antidiabetic agents and peroxisome proliferator-activated receptor (PPAR) gamma agonists, have been reported to diminish Id2 expression in human cells. We hypothesized that PPAR $\alpha$ activators may also alter Id 2 expression. Fenofibrate diminished hepatic Id 2 expression in both late pregnant and unmated rats. In 24 hour fasted rats, Id 2 expression was decreased under conditions known to activate PPAR $\alpha$. In order to determine whether the fibrate effects were mediated by PPAR $\alpha$, wild-type mice and PPAR $\alpha$-null mice were treated with Wy-14,643 (WY). WY reduced Id2 expression in wild-type mice without an effect in PPAR $\alpha$-null mice. In contrast, fenofibrate induced Id 2 expression after 24 hours of treatment in human hepatocarcinoma cells (HepG2). MK-886, a PPAR $\alpha$ antagonist, did not block fenofibrate-induced activation of Id2 expression, suggesting a PPAR $\alpha$-independent effect was involved. These findings confirm that Id 2 is a gene responsive to PPAR $\alpha$ agonists. Like other genes (apolipoprotein A-I, apolipoprotein A-V), the opposite directional transcriptional effect in rodents and a human cell line further emphasizes that PPAR $\alpha$ agonists have different effects in rodents and humans.
\end{abstract}

\section{Introduction}

Fibrates have been effectively used to reduce plasma triglyceride levels under conditions of hypertriglyceridemia [1]. The molecular basis for the action of fibrates on lipid metabolism involves the activation of transcription factors, known as peroxisome proliferator-activated receptors (PPARs), principally the PPAR $\alpha$ subtype expressed in liver ([2], for a review). Fibrates decrease the gene expression of apolipoprotein C-III, and increase the expression of fatty acid-catabolizing enzymes like acyl-coenzyme A oxidase [3] and 17 $\beta$-hydroxysteroid dehydrogenase (17 $\beta$-HSD) type IV [4] in rodent liver. Fibrates also display other effects, not directly related to the lowering of plasma lipids, including the modulation of immune and inflammatory responses. Thus, these drugs downregulate acute-phase protein expression, such as fibrinogen, C-reactive protein, and $\alpha 2$-macroglobulin [5-7].

PPARs also play an important role in glucose homeostasis. PPAR $\alpha$ agonists, by upregulating fatty acid oxidation and ketone body production, are able to spare glucose. Several studies have indicated a beneficial effect of PPAR $\alpha$ activation on insulin sensitivity $[8,9]$. Thus, hyperinsulinemia and 
hyperglycemia observed in mice subjected to a high-fat diet or in genetic insulin-resistant rodents [8] were sharply reduced by treatment with fibrates. The antidiabetic thiazolidinediones (TZD) drugs which are ligands of the PPAR $\gamma$ subtype, are prescribed for regulating glucose metabolism because they lower blood glucose by enhancing peripheral insulin sensitivity [10].

It has been shown that the levels of Id2, a member of the helix-loop-helix (HLH) transcriptional repressor protein family which includes Id1-4 [11, 12], are reduced in aortic smooth muscle cells by treatment with TZD suggesting that Id2 might play a role in their antidiabetic effects [10]. Furthermore, since glucose increases Id 2 protein levels, Id2 could contribute to changes in cellular function that occur in insulin-resistant and diabetic states [13]. Interestingly, Id2 is upregulated in muscle, fat, and liver of obese ob/ob mice [14]. Park et al. [15] have demonstrated that Id2 is a transcriptional modifier of PPAR $y$ expression and adipogenesis and found that Id 2 expression is elevated in adipose tissues of diet-induced obese mice and humans leading to the hypothesis of a role for Id2 in obesity and insulin resistance. Furthermore, Id 2 nullizygous mice show altered expression of genes involved in lipid metabolism which could be related to reduced lipid storage in liver and white adipose tissue [16]. These authors also found that genes involved in glucose homeostasis exhibited altered expression in Id2-null mice.

Id proteins participate in development, cell cycle control, differentiation, and tumorigenesis [17]. Id2 protein heterodimerizes with E proteins, a subset of basic HLH (bHLH) transcription factors [18] and sterol regulatory element-binding protein-1c (SREBP)-1c [19], but because Id2 lacks a DNA binding domain, Id2 acts as a dominant negative regulator of these transcription factors [11]. Additionally, Id2 is able to regulate the function of HLH transcription factors indirectly by sequestering $\mathrm{E}$ proteins [18].

Changes in lipid metabolism and insulin resistance during late pregnancy are comparable to that normally seen in type 2 diabetic patients, in which the use of fibrates is recommended [20]. For that reason, late pregnancy has been previously used by our group [2, 21-24] and other authors [25-28] to study the effect of PPAR agonists. We have used these experimental settings to discover new PPAR $\alpha$ target genes in rodents [7]. Thus, we have used late-gestation rats to study the effect of fibrates in hepatic Id2 mRNA expression. In addition, since free fatty acids (FFA) are known to act as PPAR $\alpha$ activators and fasting increases circulating FFA [29-31], the role of FFA on the Id2 mRNA expression was investigated in fasted rats. Furthermore, in order to determine whether the effect of fibrates on Id2 gene expression is mediated by PPAR $\alpha$, wild-type and PPAR $\alpha$ null mice were used. Finally, in order to study whether the effect of fibrates on Id2 gene expression is species-specific, the human hepatocarcinoma cell line (HepG2) was used as a model system.

\section{Materials and Methods}

\subsection{Animals, Drug Administration, and Collection of the Samples}

Study I. Female Sprague-Dawley rats weighing 180-210 g were fed ad libitum standard rat chow (B\&K Universal, Barcelona, Spain) and housed under controlled light and temperature conditions ( $12 \mathrm{~h}$ light-dark cycle; $22 \pm 1^{\circ} \mathrm{C}$ ). The experimental protocol was approved by the Animal Research Committee of the University San Pablo-CEU, Madrid, Spain. Half the animals were mated, and day 0 of pregnancy was determined by the appearance of spermatozoids in vaginal smears, whereas the remaining half were kept virgin. From day 16 of gestation, rats were given by oral gavage two daily doses of 0,100 or $200 \mathrm{mg}$ of fenofibrate (Sigma-Aldrich, St Louis, MO, USA)/kg of body weight, one at $8.00 \mathrm{~h}$ and the other at $18.00 \mathrm{~h}$, suspended in $2 \%$ Tween80 or Tween-80 alone. On the morning of the 20th day of pregnancy (after 4 days of treatment), corresponding to $14 \mathrm{~h}$ after receiving the last treatment, rats were decapitated and blood collected using tubes containing $\mathrm{Na}_{2}$-EDTA. Liver was immediately removed, placed in liquid nitrogen and kept at $-80^{\circ} \mathrm{C}$ until analysis. Virgin rats received the same treatment and were studied in parallel. There were 5-6 animals per group.

Study II. Female Sprague-Dawley rats weighing 180-210 g were mated, and half the animals were subjected to fasting for $24 \mathrm{~h}$ at day 19 of pregnancy. At day 20 of pregnancy, blood and liver were collected as before. Plasma aliquots were kept at $-20^{\circ} \mathrm{C}$ until processing for the analysis of FFA by enzymatic commercial kit (Wako Chemicals GmbH, Neuss, Germany).

Study III. Male SV129 wild-type mice were purchased from Taconic (Germantown, NY, USA), and male SV129 PPAR $\alpha$ null mice [32] were a kind gift from Frank Gonzalez (National Cancer Institute, Bethesda, MD, USA). Control and treated mice $(n=2-5)$ were provided NIH-07 rodent chow (Ziegler Brothers, Gardner, PA, USA) and water ad libitum. This study was conducted under federal guidelines for the use and care of laboratory animals and was approved by the Chemical Industry Institute of Toxicology Institutional Animal Care and Use Committee (NC, USA). Lighting was on a $12 \mathrm{hr}$ light/dark cycle. Mice were fed diet supplemented with either Wy-14,643 (WY) (ChemSyn Science Laboratories, Lenexa, KS, USA) (0.1\%) or di-(2-ethylhexyl)phthalate (DEHP) (Aldrich Chemical, Milwaukee, WI, USA) $(0.6 \%)$, or a control diet for 3 weeks. WY and DEHP were selected because of their different structural properties and uses. DEHP is considered a weak PPAR activator compared to WY. At the designated time after treatment, animals were anesthetized by pentobarbital injection and killed by exsanguination. Livers were removed, rinsed with isotonic saline, snap-frozen in liquid nitrogen, and stored at $-80^{\circ} \mathrm{C}$ until analysis. 
Study IV. Human hepatocarcinoma cells (HepG2) were obtained from American Type Culture Collection (HB8065) (Manassas, VA, USA) and cultured in EMEM media, supplemented with $1 \%$ glutamine, $1 \%$ nonessential amino acids, $3 \%$ antibiotics $(100 \mathrm{U} / \mathrm{mL}$ penicillin and $100 \mu \mathrm{L} / \mathrm{mL}$ streptomycin), and $10 \%$ fetal bovine serum. All cells were grown in a $5 \% \mathrm{CO}_{2}$-humidified atmosphere at $37^{\circ} \mathrm{C}$. After confluence, cells were cultured in serum-free medium (with $0.1 \%$ BSA) for 24 hours and different concentrations of fenofibrate $(0,10,50$, and $100 \mu \mathrm{M})$ in DMSO were added. After different times of incubation (2, 6, and 24 hours), media was collected and cells were washed with ice-cold PBS and removed with a cell scraper. After centrifugation, cell pellets were frozen and used for RNA extraction. In some cases, cells were preincubated for 30 minutes [33] with the PPAR $\alpha$ antagonist MK-886 (Enzo Life Sciences Inc., Farmingdale, NY, USA) $(10 \mu \mathrm{M})$ dissolved into DMSO. DMSO concentration in culture medium did not exceed $0.1 \%$. An additional experiment was carried out in the same conditions as described above but the cells were instead cultured in serum-free medium for 36 hours, and then treated with the drugs.

\subsection{Total RNA Preparation and Analysis}

Studies I and II. Rat total hepatic RNA was isolated by a modification of the guanidium isothiocyanate method using Ultraspec RNA according to the manufacturer's instructions (Biotecx Labs, Houston, USA). Total RNA concentration was determined by absorbance measurement at $260 \mathrm{~nm}$. The 260/280 absorption ratio of all samples was between 1.8 and 2.0. Total RNA-genomic DNA-free samples were used to analyse the expression of Id2 gene and glyceraldehyde-3-phosphate dehydrogenase (GAPDH) as endogenous control, by semiquantitative RT-PCR, according to previously described protocols $[7,24]$. Briefly, total RNA $(2.5 \mu \mathrm{g})$ was digested with $5 \mathrm{U}$ RNase free-DNaseI (Roche, USA) for 20 minutes at $37^{\circ} \mathrm{C}$ to remove traces of genomic DNA. The DNase was inactivated at $64^{\circ} \mathrm{C}$ for 10 minutes and cDNA was synthesized from total RNA by oligo(dT)-primed reverse transcription with Superscript II (Invitrogen, Life Technologies Ltd., Paisley, UK), according to the manufacturer's instructions. PCRs were performed in a $25 \mu \mathrm{L}$ reaction mix containing $20 \mathrm{pmol}$ of both forward and reverse primer, $10 \mathrm{mmol} / \mathrm{L}$ of each deoxyribonucleoside triphosphate, appropriate dilutions of the cDNA stock, $2.5 \mu \mathrm{L}$ of PCR 10X buffer, and Accu Taq-polymerase (SigmaAldrich, St Louis, MO, USA). The sense and antisense primer sequences were $5^{\prime}$-GAAAAACAGCCTGTCGGACCA- $3^{\prime}$ and 5'-CCAGGGCGATCTGCAGGT-3' for Id2 (205 bp product); and $5^{\prime}$-ACCACAGTCCATGCCATCAC- $3^{\prime}$ and $5^{\prime}$ TCCACCACCCTGTTGCTGT- $3^{\prime}$ for GAPDH ( $450 \mathrm{bp}$ product) $[34,35]$.

All reactions were performed in a PTC-100 Thermocycler (MJ Research, USA) in which samples underwent a $3 \mathrm{~min}$ initial denaturing step, followed by 35 cycles of $45 \mathrm{~s}$ to $1 \mathrm{~min}$ at $94^{\circ} \mathrm{C}, 45 \mathrm{~s}$ at the annealing temperature of $65^{\circ} \mathrm{C}$ for Id 2 and $57^{\circ} \mathrm{C}$ for GAPDH, and a primer extension step at $72^{\circ} \mathrm{C}$ for $45 \mathrm{~s}$ to $1 \mathrm{~min}$. The final extension step was $10 \mathrm{~min}$ at $72^{\circ} \mathrm{C}$. The PCR products were analysed by agarose gel electrophoresis and DNA was visualized by ethidium bromide staining and using a UV-light box. Band intensity was determined by quantitative scanning densitometry (GS700 Imaging Densitometer, BioRad, Hercules, CA, USA). To determine the linear range of the PCR, dilutions of the cDNA preparations were previously used for each gene and experimental group of rats. Results were normalized to the control gene (GAPDH).

Study III. Total RNA was isolated from mouse livers by a modification of the guanidinium isothiocyanate method using RNAzol according to manufacturer's instructions (TelTest, Friendswood, TX, USA). Twenty $\mu \mathrm{g}$ of denatured total RNA was separated on $1.2 \%$ agarose gels and transferred to nylon membranes in 20x SSC. The DNA probes for Northern blot analysis were labeled with $\left[\alpha-{ }^{32} \mathrm{P}\right] \mathrm{dCTP}$ using the random primer DNA labelling kit provided by Amersham. Probes used were a rat L-bifunctional enzyme (Ehhadh) cDNA fragment, the complete cDNA of rat $17 \beta$-HSD type IV [4] and the PCR products generated as indicated above in the studies I and II, and using rat CDNA as a template. The probes were sequenced (ABI PRISM 377 Perkin Elmer DNA sequencer), and the sequences obtained were compared to Gene Bank sequences to confirm the accuracy of the probes used. Blots were prehybridized at $42^{\circ} \mathrm{C}$ for $2 \mathrm{~h}$ and hybridized overnight at the same temperature. Washing conditions were $0.1 \mathrm{x}$ SSC, $0.1 \%$ SDS at $53^{\circ} \mathrm{C}$ for $15 \mathrm{~min}$ three times, and membranes were exposed to appropriate screens (Imaging Screen $\mathrm{K}$, BioRad) at $4^{\circ} \mathrm{C}$ from $1 \mathrm{~h}$ to three days and the images analyzed (Personal Molecular Imager FX, BioRad). Filters were stripped of label at $75-80^{\circ} \mathrm{C}$ for $1 \mathrm{~h}$ with $0.1 \mathrm{x}$ SSC, $0.5 \%$ SDS, $0.1 \%$ tetrasodium pyrophosphate and then rehybridized.

Study IV. Total RNA was isolated from HepG2 cell pellets by QIAcube automated protocol using spin-column kit (RNeasy Mini Kit, QIAGEN, Hilden, Germany). Total RNA concentration was determined by absorbance measurement at $260 \mathrm{~nm}$. The 260/280 absorption ratio of all samples was between 1.8 and 2.0. Total RNA-genomic DNA-free samples were used to analyse the expression of Id2 and $\beta$-actin as a control, by reverse transcription and quantitative real time PCR (qPCR) assays, according to the following protocol: cDNA was synthesized from $1 \mu \mathrm{g}$ total RNA by Transcriptor high fidelity cDNA synthesis kit (Roche, Mannheim, Germany), according to the manufacturer's instructions. qPCRs were performed in a $20 \mu \mathrm{L}$ reaction mix containing $20 \mathrm{pmol}$ of both forward and reverse primer, SYBR Premix Ex Taq (Takara Bio Inc., Tokyo, Japan) and cDNA. Sense and antisense primer sequences were $5^{\prime}$-GAA AGCCTTCAGTCCCGTGAGGTCCGTT- $3^{\prime}$ and $5^{\prime}$-CTG GTGATGCAGGCTGACAATAGTGGGATG-3' for Id2 (271 bp) (Atlas RT-PCR Primer Sequences (Clontech, CA, USA); $5^{\prime}$-CCTGGCACCCAGCACAAT- $3^{\prime}$ and 5'-GGGCCGGAC TCGTCATAC- $3^{\prime}$ for $\beta$-actin (145bp) [36]. Samples were analyzed in duplicate. All reactions were performed in a 

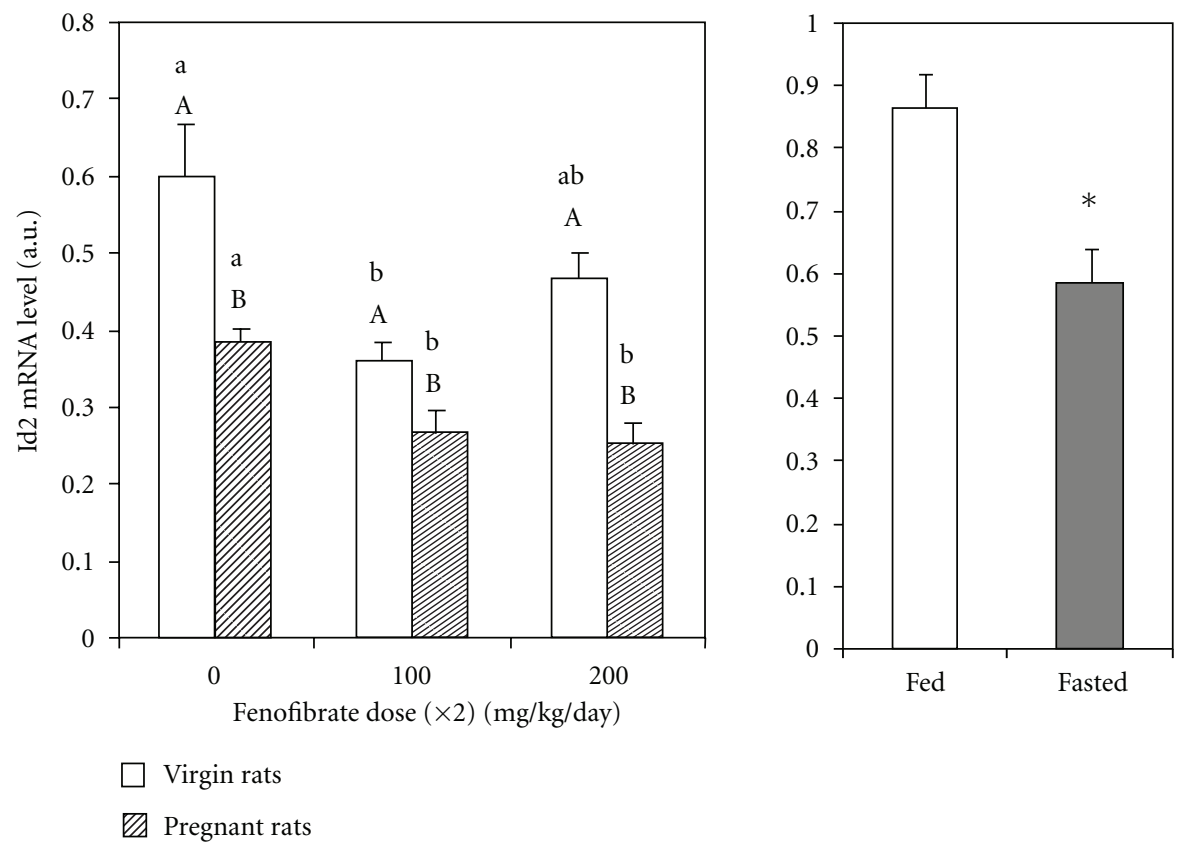

FIGURE 1: Fenofibrate downregulates Id2 gene expression in rats. Left panel: relative amount of mRNA of liver Id2, after 4-day treatment with or without fenofibrate in virgin and pregnant rats, measured by semiquantitative RT-PCR. Values were normalized against glyceraldehyde3-phosphate dehydrogenase (GAPDH) expression and were represented using arbitrary units. Capital letters correspond to the statistical comparisons between pregnant and virgin rats receiving the same treatment. Small letters correspond to the statistical comparisons between rats receiving different drug doses. Values not sharing a common letter are significantly different at $P<0.05$. Each value represents the mean \pm standard error of five animals. Right panel: starvation downregulates Id2 gene expression. Relative amount of mRNA of liver Id2 from pregnant rats fed with standard pellet or fasted $24 \mathrm{~h}$, measured by semiquantitative RT-PCR. Values were normalized against GAPDH expression and were represented using arbitrary units. Asterisk represents significantly different at $P<0.05$.

LightCycler 5.0 (Roche). Optimal qPCR efficiency and linearity were previously confirmed for each target. Results for the expression of Id2 mRNA were expressed relative to the control gene ( $\beta$-actin).

2.3. Statistical Analysis. Results were expressed as means \pm S.E. Treatment effects were analyzed by one-way analysis of variance (ANOVA). When treatment effects were significantly different $(P<0.05)$, means were tested by Tukey multiple range test. For nonparametric data, the MannWhitney $U$ test was used with differences between the two groups analyzed by Student $t$-test.

\section{Results}

3.1. Effect of Fenofibrate on Id2 Expression in Pregnant and Virgin Rats. As shown in Figure 1, hepatic Id2 mRNA levels were higher in virgin than in pregnant rats in the absence of treatment. In nonpregnant rats, hepatic Id2 mRNA levels were decreased by treatment with fenofibrate, although the effect at higher dose was not significant. PPAR $\alpha$ agonist treatment for 4 days also decreased Id 2 mRNA levels in pregnant rats (Figure 1) independently of the dose used, indicating that the lower dose was sufficient to reduce the expression of the Id2 gene. These results validate those previously found by our group when Id2 levels were evaluated using the same samples by macroarray technology (Atlas Nylon Arrays,
Clontech, BD Biosciences, Palo Alto, CA, USA) (unpublished results).

3.2. Effect of Fasting on Id2 Expression. It is well known that several types of fatty acids are PPAR $\alpha$ activators $[29,30]$. The uptake of fatty acids into the liver as a result of their mobilization from adipose tissue after fasting would result in PPAR $\alpha$ activation and changes in the expression of its target genes [31]. Plasma FFA levels in fed rats were $360.84 \pm$ $22.15 \mu \mathrm{M}$, significantly different $(P<0.05)$ from those levels found in $24 \mathrm{~h}$ fasted rats: $1,503.90 \pm 157.81 \mu \mathrm{M}$. As shown in Figure 1, $24 \mathrm{~h}$ fasting produced a significant decrease in hepatic expression of Id 2 in comparison to the rats fed ad libitum correlating to the increase in circulating fatty acids.

3.3. Requirement for PPAR $\alpha$ in Fibrate Regulation of Id2 Expression. Because PPAR $\alpha$ has been shown to mediate several fibrate-inducible responses in the liver, we examined the dependence of fibrate-induced decreases in Id2 gene regulation on PPAR $\alpha$ expression. Wild-type mice and PPAR $\alpha$ null mice [32] were fed a control diet or the same diet supplemented with either WY $(0.1 \%)$ or DEHP $(0.6 \%)$ for 3 weeks. As shown in Figure 2, when wild-type mice were fed WY there was a significant decrease in the liver expression of Id2 mRNA, whereas treatment with DEHP, a weaker PPAR $\alpha$ activator, did not change the levels of Id2 mRNA. Treatment 

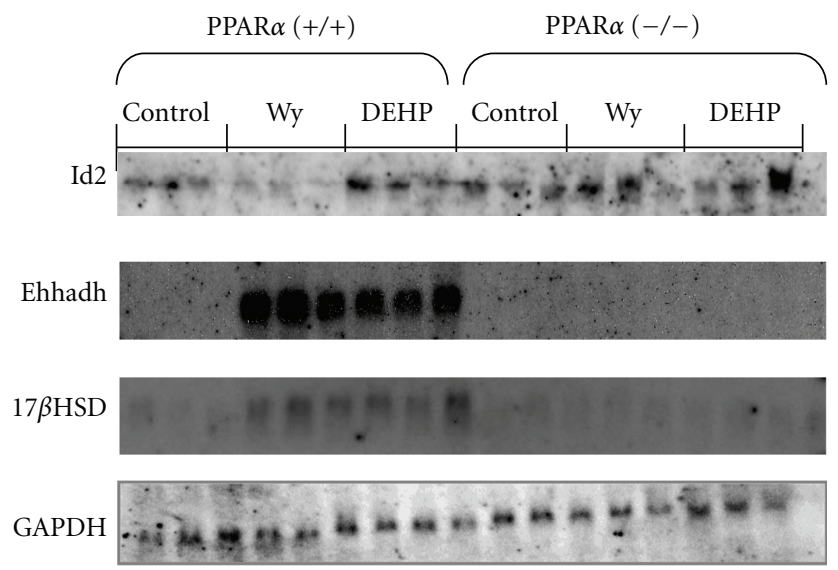

(a)
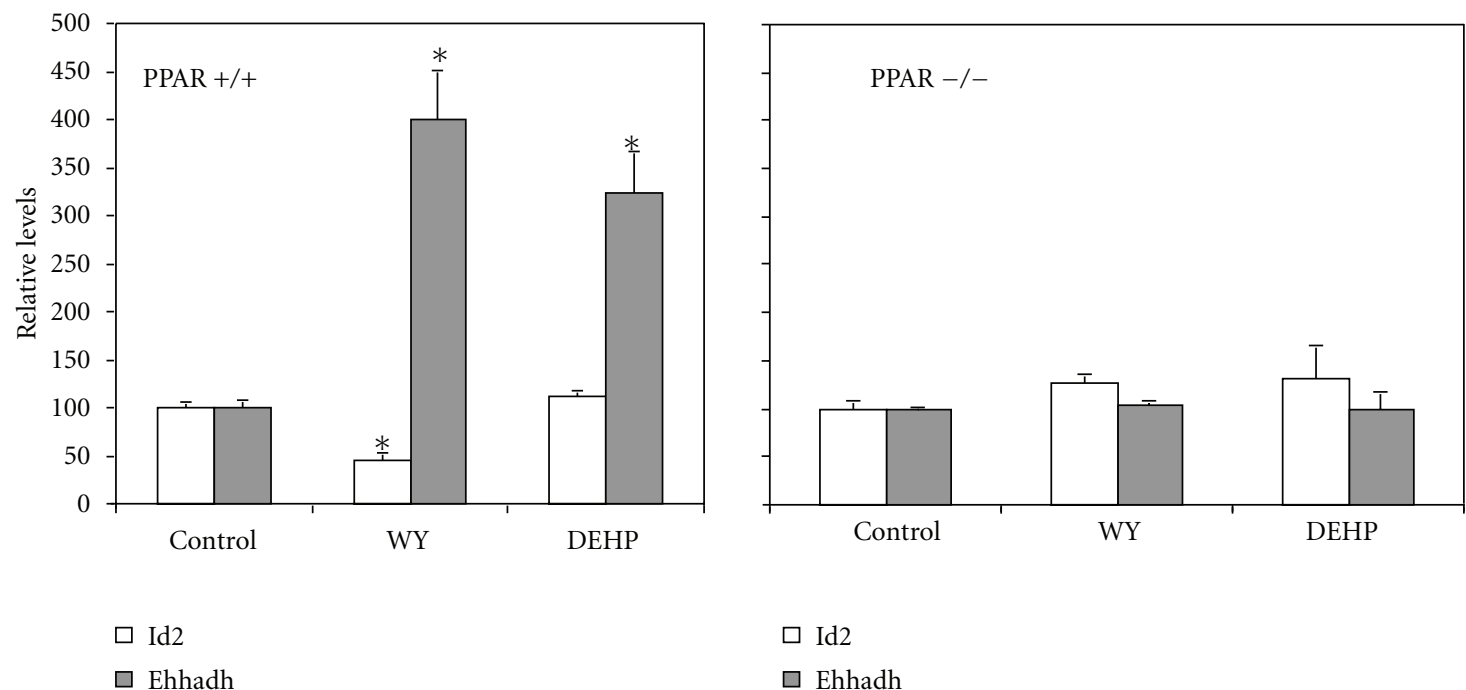

(b)

FIgURE 2: Downregulation of Id2 gene expression by WY is dependent on PPAR $\alpha$. Wild-type SV129 mice (+/+) or SV129 mice that lack $\operatorname{PPAR} \alpha(-/-)$ were fed a control diet (Control) or a diet containing WY $(0.1 \%)$ or DEHP $(0.6 \%)$ for 3 weeks. Total RNA isolated from liver was separated by $1.2 \%$ agarose, transferred to nylon, and analysed by northern blot using probes for Id2, Ehhadh, and 17 $\beta$ HSD, and GAPDH as a control. Northern autoradiograms (a) were densitometrically scanned and expression normalized to that of GAPDH (b). Each value represents the mean \pm standard error of three animals. * significantly different from control $(P<0.05)$.

of PPAR $\alpha$-null mice with WY or DEHP resulted in no change in Id2 gene expression (Figure 2).

As a positive control of $\operatorname{PPAR} \alpha$ agonist regulation of gene expression, we also examined the levels of L-bifunctional enzyme (Ehhadh) mRNA. As expected [37, 38], Ehhadh mRNA expression was significantly enhanced by WY or DEHP treatments in wild-type mice but not in PPAR $\alpha$ null mice (Figure 2). A similar effect was found for $17 \beta$ HSD type IV gene expression (Figure 2), in accordance with our previously published results [4]. As a negative control, GAPDH mRNA levels remained constant under all conditions (Figure 2).

3.4. Effect of Fenofibrate on Id2 Expression in Human Cultured Cells. Since fibrates depressed Id2 hepatic expression in rodents in a PPAR $\alpha$ mediated manner, we also determined if Id2 mRNA expression exhibits a similar behaviour in human cells. Unexpectedly, fenofibrate at 50 and $100 \mu \mathrm{M}$ increased Id 2 mRNA expression after 24 hours of treatment (Figure 3(a)). A previous report has shown that glucose could induce Id2 expression in cultured cells [13]. The EMEM media used here contained $5 \mathrm{mM}$ glucose, therefore, we repeated the experiment in the presence of $20 \mathrm{mM}$ glucose. The results observed in the presence of additional glucose were similar to those described in Figure 3(a) (data not shown).

To determine if the activation of Id2 expression is mediated by PPAR $\alpha$ in HepG 2 cells, the cells were preincubated with the PPAR $\alpha$ antagonist MK-886 [39]. As shown in Figure 3(b), the effect of fenofibrate was not blocked by preincubation with $\mathrm{MK}-886$, indicating that the induction 


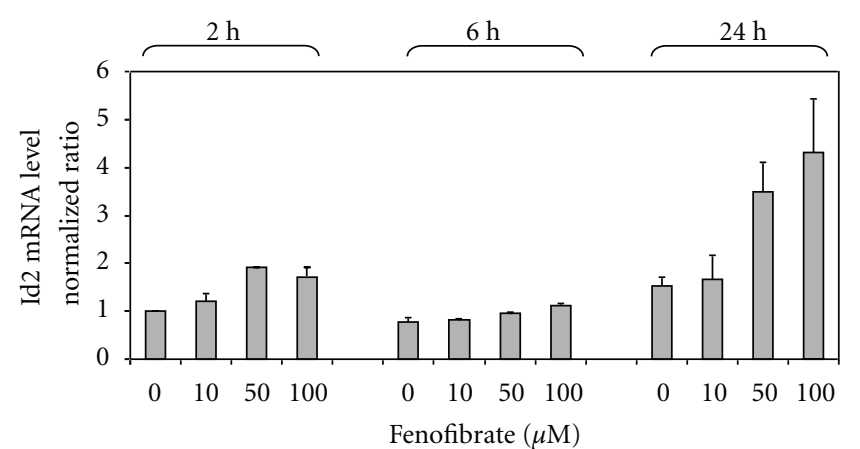

(a)

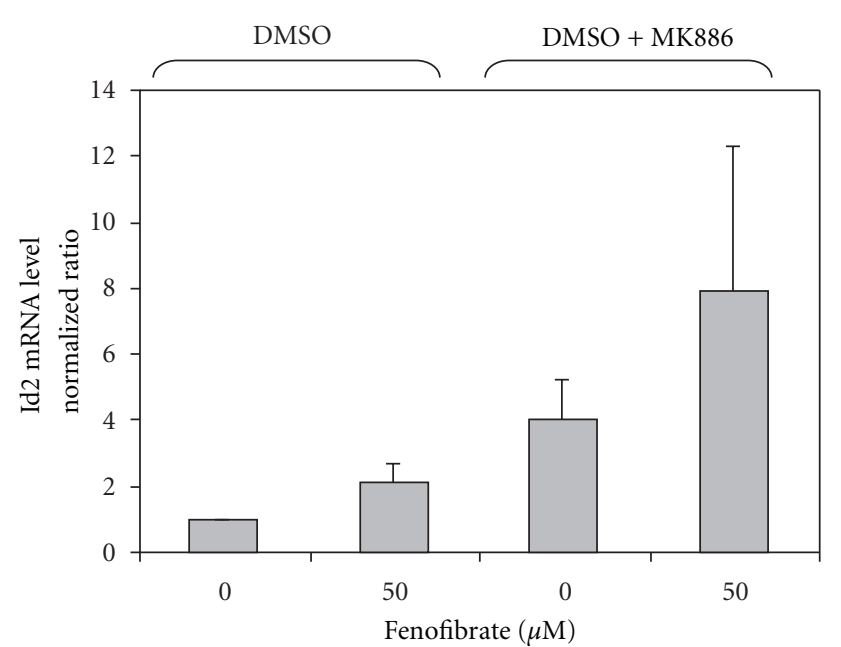

(b)

Figure 3: Fenofibrate upregulates Id2 gene expression in HepG2 cells. Panel (a) human hepatocarcinoma cells treated with different concentrations of fenofibrate $(0,10,50$, or $100 \mu \mathrm{M})$ for 2, 6, or 24 hours. Relative Id 2 mRNA levels were measured by real-time PCR, normalized to $\beta$-actin levels and expressed in relative units to control. Values for Id $2 \mathrm{mRNA}$ are expressed as mean $\pm \mathrm{SD}(n=3)$. Panel (b) HepG2 cells were preincubated with the PPAR $\alpha$ antagonist MK-886 $(10 \mu \mathrm{M})$ where indicated and treated with different concentrations of fenofibrate $(0$ or $50 \mu \mathrm{M})$ for 24 hours.

was independent of PPAR $\alpha$. Instead, the PPAR $\alpha$ antagonist showed an additive effect with fenofibrate on Id2 mRNA expression (Figure 3(b)). Glutathione S-transferase pi 1 (Gstp1), which expression has been recently shown to be modified by PPAR $\alpha$ activators [40], was also measured. Fenofibrate increased Gstp1 expression (1.7-fold induction versus control without drug), whereas MK-886 abolished the effect of fenofibrate on HepG2 cells.

A recent report showed that Id 2 expression could be influenced by circadian rhythm [16], and it has been previously established that serum is able to induce circadian gene expression [41, 42]. Therefore, an additional experiment was carried out with MK886 and fenofibrate, in which the cells were cultured in serum-free medium for 36 hours instead of 24 hours. Similar results to those observed in Figure 3(b) were obtained when the serum was substituted with BSA, 36 hours before the treatment with the drugs (data not shown).

\section{Discussion}

In this study, we found that fenofibrate treatment repressed liver Id 2 mRNA expression both in pregnant and virgin rats. These findings agree with those of Yamazaki et al. [43] using cDNA microarrays from mice after 2 or 3 days oral administration of fenofibrate $(100 \mathrm{mg} / \mathrm{kg})$ or WY $(30 \mathrm{mg} / \mathrm{kg})$, and are consistent with those reported by Wong and Gill [44] after 1.0\% DEHP in the diet for 13 weeks as studied by microarrays.

Glucocorticoids, whose circulating levels are augmented during pregnancy [45], have been described as repressors of Id2 expression in cells [46]. In agreement with this, basal levels of Id 2 mRNA in pregnant rats were lower than in unmated rats, the difference being also observed after fenofibrate treatment. These findings emphasize the downregulatory effect of PPAR $\alpha$ agonists, independent of whether Id 2 mRNA levels are low, as in gestation, or elevated as in nonpregnant rats.

Fasting produces mobilization of fatty acids from adipose tissue. Fatty acids are natural activators of PPAR $\alpha[29,31$, 47]. Therefore, the arrival of fatty acids in the liver as result of starvation, led to a significant decrease in hepatic expression of Id2. This finding reinforces the idea that PPAR $\alpha$ activation produces a decrease in Id 2 mRNA expression in liver.

Id2-null mice exhibit a decrease in adipose tissue and liver fat deposition compared to wild-type mice [16]. Consistent with that, Id2-overexpressing adipocytes show increased capacity for morphological differentiation and lipid accumulation [15]. In contrast, we found that PPAR $\alpha$ activators decrease Id2 gene expression under the same conditions as we had previously reported an accumulation of lipids in the liver. Thus, hepatic triglyceride content in fasted rats was higher in comparison to fed condition [48], and it was also augmented in nonpregnant fenofibrate treated rats (in comparison to nontreated unmated rats) [24]. Nevertheless, although Id2 mRNA expression was also modified by fenofibrate in late gestation, hepatic triglyceride content was not affected by the drug in pregnant rats [24].

Since it has been reported that Id 2 inhibits lipogenesis by interfering with the transcriptional activity of SREBP1c at the fatty acid synthase (FAS) promoter [19], our results might reflect an increased lipogenesis along with an Id2 repression. However, the hepatic expression of FAS was not significantly changed by fenofibrate in virgin or in pregnant rats [24], and $24 \mathrm{~h}$ fasting instead decreased FAS expression in pregnant rats (unpublished results).

We found a decrease in the expression of Id 2 in mice treated with WY-14,643, yet this effect was not seen with 
DEHP, indicating that the effect depends on PPAR $\alpha$ activator potency. In the case of mice that lacked a functional form of PPAR $\alpha$, differences were not observed after the different treatments, suggesting that it was an effect mediated by PPAR $\alpha$. This finding is in agreement with that one recently described by el Azzouzi et al. [49] in murine cardiomyocyte cells using cDNA microarrays. One of gene listed by these authors to be specifically downregulated by WY was Id2. However, neither GW-5015160 (a PPAR $\beta / \delta$ agonist) nor rosiglitazone (a PPAR $\gamma$ agonist) produced any change. Thus, it can be assumed that fibrates affect Id2 gene expression through PPAR $\alpha$.

The decrease found in the expression of Id 2 in mice by the potent PPAR $\alpha$ activator WY agrees with the reduction observed in rats treated with fenofibrate. Since, it appears that both STAT3 and C/EBP $\beta$ are involved in regulation of Id $2[50,51]$, and it is known that PPAR $\alpha$ activation interferes with signalling pathways dependent on C/EBP and STAT [52], we hypothesize that PPAR $\alpha$ may negatively regulate Id2 through inhibition of STAT3 or C/EBP.

In contrast to rodents, the negative effect of fibrates on Id2 gene expression was not observed in human cells. Fenofibrate enhanced Id 2 mRNA levels in these cells after a $24 \mathrm{~h}$ incubation. Moreover, since Grønning et al. [13] have shown in murine macrophages that glucose induces increases in protein levels of this transcriptional repressor, we studied the effect of fibrates both at low glucose and high glucose and found a similar fenofibrate-inducing effect on Id 2 mRNA expression. The effect of fenofibrate was observed after 24-h incubation, suggesting that regulation of Id2 expression by PPAR might occur by an indirect mechanism [53]. Nevertheless, several PPAR $\alpha$ target genes [54] were also induced after 24-hour administration of fibrates but not earlier. Therefore, we studied the effect of MK-886, an antagonist of PPAR $\alpha$ and found that fenofibrate-induced increases in Id 2 mRNA expression were not abolished by preincubation with MK-886, confirming that the effect was not mediated by PPAR $\alpha$. In accordance with this finding, TZD, which also modulate Id2 mRNA levels in cultured human cells, use a PPAR $\gamma$-independent mechanism [10]. Fenofibrate and MK-886 functioned synergistically to stimulate Id2 expression. The MK-886-induced increase in Id 2 mRNA expression could be caused by two mechanisms: (i) specific inactivation of PPAR $\alpha$; (ii) other pathways, such as inhibition of leukotriene biosynthesis [39]. Therefore, it is assumed that fenofibrate-induced increases in Id 2 expression occur by a PPAR $\alpha$-independent mechanism. How fenofibrate increases Id2 expression in HepG2 cells remains elusive.

Finally, Id proteins are HLH transcription factors that participate in development, cell cycle control, differentiation, and tumorigenesis [17]. However, the role of Id2 protein in the mechanism of action of fibrates has not been elucidated. Altogether, these findings confirm that Id2 gene expression is responsive to PPAR $\alpha$ activators (fibrates and possibly fatty acids). However, as reported for other genes (apoA-I, apoAV) ([2] and references therein), the effects are opposite in rodents versus humans. Since peroxisome proliferators function as hepatocarcinogenic agents in rodents, but not in humans [55], and considering the role of Id2 protein in cell proliferation and cancer [17], we speculate that the differential response to fibrate exposure might be related to the differences in liver tumorigenesis between species.

\section{Abbreviations}

PPAR: Peroxisome proliferator-activated receptor GAPDH: Glyceraldehyde-3-phosphate dehydrogenase Id2: $\quad$ Inhibitor of DNA binding 2

DEHP: Di-(2-ethylhexyl)phthalate

WY: WY-14,643

RT-PCR: Reverse transcriptase polymerase chain reaction

EMEM: Eagle's minimal essential medium

A.U.: $\quad$ Arbitrary units.

\section{Acknowledgments}

The authors would like to thank Plan Nacional de Investigación Científica, Desarrollo e Innovación Tecnológica $(\mathrm{I}+\mathrm{D}+\mathrm{i})$, Instituto de Salud Carlos III-Subdirección General de Evaluación y Fomento de la Investigación (PI-09/02192), and European Community FEDER funds, as well as the Fundación Universitaria San Pablo-CEU (USP-PC 17/09) for financial support. M. Carmen González was a recipient of a predoctoral fellowship from the Universidad San PabloCEU, Madrid, Spain. The authors thank Milagros Morante for her excellent technical assistance and Drs. Mitch Rosen and Sheau-Fung Thai for a critical review of the paper. The information in this document has been supported by the U.S. Environmental Protection Agency. It has been subjected to review by the National Health and Environmental Effects Research Laboratory and approved for publication. Approval does not signify that the contents reflect the views of the Agency, nor does mention of trade names or commercial products constitute endorsement or recommendation for use.

\section{References}

[1] G. F. Watts and S. B. Dimmitt, "Fibrates, dyslipoproteinaemia and cardiovascular disease," Current Opinion in Lipidology, vol. 10, no. 6, pp. 561-574, 1999.

[2] M. I. Panadero, M. C. González, E. Herrera, and C. Bocos, "Factors modulating fibrates response: therapeutic implications and alternative strategies," Endocrine, Metabolic and Immune Disorders, vol. 9, no. 3, pp. 219-236, 2009.

[3] A. M. Lefebvre, J. Peinado-Onsurbe, I. Leitersdorf et al., "Regulation of lipoprotein metabolism by thiazolidinediones occurs through a distinct but complementary mechanism relative to fibrates," Arteriosclerosis, Thrombosis, and Vascular Biology, vol. 17, no. 9, pp. 1756-1764, 1997.

[4] J. C. Corton, C. Bocos, E. S. Moreno et al., "Rat $17 \beta-$ hydroxysteroid dehydrogenase type IV is a novel peroxisome proliferator-inducible gene," Molecular Pharmacology, vol. 50, no. 5, pp. 1157-1166, 1996.

[5] J. C. Corton, L.-Q. Fan, S. Brown et al., "Down-regulation of cytochrome P450 2C family members and positive acutephase response gene expression by peroxisome proliferator chemicals," Molecular Pharmacology, vol. 54, no. 3, pp. 463473, 1998. 
[6] P. Gervois, R. Kleemann, A. Pilon et al., "Global suppression of IL-6-induced acute phase response gene expression after chronic in vivo treatment with the peroxisome proliferatoractivated receptor- $\alpha$ activator fenofibrate," Journal of Biological Chemistry, vol. 279, no. 16, pp. 16154-16160, 2004.

[7] M. C. Gonzalez, J. C. Corton, R. C. Cattley, E. Herrera, and C. Bocos, "Peroxisome proliferator-activated receptor $\alpha(\operatorname{PPAR} \alpha)$ agonists down-regulate $\alpha 2$-macroglobulin expression by a PPAR $\alpha$-dependent mechanism," Biochimie, vol. 91, no. 8, pp. 1029-1035, 2009.

[8] M. Guerre-Millo, P. Gervois, E. Raspé et al., "Peroxisome proliferator-activated receptor $\alpha$ activators improve insulin sensitivity and reduce adiposity," Journal of Biological Chemistry, vol. 275, no. 22, pp. 16638-16642, 2000.

[9] C. J. Chou, M. Haluzik, C. Gregory et al., "WY14,643, a peroxisome proliferator-activated receptor $\alpha$ (PPAR $\alpha$ ) agonist, improves hepatic and muscle steatosis and reverses insulin resistance in lipoatrophic A-ZIP/F-1 mice," Journal of Biological Chemistry, vol. 277, no. 27, pp. 24484-24489, 2002.

[10] X. Zhu, Y. Lin, J. Zhang, M. Fu, Z. Mao, and Y. E. Chen, "Thiazolidinediones, a class of anti-diabetic drugs, inhibit Id2 expression through a PPAR $\gamma$-independent pathway in human aortic smooth muscle cells," Cellular and Molecular Life Sciences, vol. 60, no. 1, pp. 212-218, 2003.

[11] J. D. Norton, R. W. Deed, G. Craggs, and F. Sablitzky, "Id helixloop-helix proteins in cell growth and differentiation," Trends in Cell Biology, vol. 8, no. 2, pp. 58-65, 1998.

[12] Y. Yokota, S. Mori, O. Narumi, and K. Kitajima, "In vivo function of a differentiation inhibitor, Id2," IUBMB Life, vol. 51, no. 4, pp. 207-214, 2001.

[13] L. M. Grønning, R. Tingsabadh, K. Hardy et al., "Glucose induces increases in levels of the transcriptional repressor Id2 via the hexosamine pathway," American Journal of Physiology, vol. 290, no. 4, pp. E599-E606, 2006.

[14] D. Vicent, M. Piper, S. Gammeltoft, E. Maratos-Flier, and R. C. Kahn, "Alterations in skeletal muscle gene expression of ob/ob mice by mRNA differential display," Diabetes, vol. 47, no. 12, pp. 1451-1458, 1998.

[15] K. W. Park, H. Waki, C. J. Villanueva et al., "Inhibitor of DNA binding 2 is a small molecule-inducible modulator of peroxisome proliferator-activated receptor- $\gamma$ expression and adipocyte differentiation," Molecular Endocrinology, vol. 22, no. 9, pp. 2038-2048, 2008.

[16] T. Y. Hou, S. M. Ward, J. M. Murad, N. P. Watson, M. A. Israel, and G. E. Duffield, "ID2 (inhibitor of DNA binding 2) is a rhythmically expressed transcriptional repressor required for circadian clock output in mouse liver," Journal of Biological Chemistry, vol. 284, no. 46, pp. 31735-31745, 2009.

[17] M. B. Ruzinova and R. Benezra, "Id proteins in development, cell cycle and cancer," Trends in Cell Biology, vol. 13, no. 8, pp. 410-418, 2003.

[18] J. D. Norton, "ID helix-loop-helix proteins in cell growth, differentiation and tumorigenesis," Journal of Cell Science, vol. 113, no. 22, pp. 3897-3905, 2000.

[19] M. Moldes, M. Boizard, X. Le Liepvre, B. Fève, I. Dugail, and J. Pairault, "Functional antagonism between inhibitor of DNA binding (Id) and adipocyte determination and differentiation factor $1 /$ sterol regulatory element-binding protein1c (ADD1/SREBP-1c) trans-factors for the regulation of fatty acid synthase promoter in adipocytes," Biochemical Journal, vol. 344, no. 3, pp. 873-880, 1999.

[20] C. Rustemeijer, J. A. Schouten, H. J. Voerman, H. E. S. J. Hensgens, A. J. M. Donker, and R. J. Heine, "Pravastatin compared to bezafibrate in the treatment of dyslipidemia in insulintreated patients with Type 2 diabetes mellitus," Diabetes/Metabolism Research and Reviews, vol. 16, pp. 82-87, 2000.

[21] F. Villarroya, C. Bocos, M. Giralt et al., "Pharmacological and Gene modification-based models for studying the impact of perinatal metabolic disturbances in adult life," Advances in Experimental Medicine and Biology, vol. 646, pp. 141-148, 2009.

[22] J. Sevillano, J. de Castro, C. Bocos, E. Herrera, and M. P. Ramos, "Role of insulin receptor substrate-1 serine 307 phosphorylation and adiponectin in adipose tissue insulin resistance in late pregnancy," Endocrinology, vol. 148, no. 12, pp. 5933-5942, 2007.

[23] A. Soria, C. Bocos, and E. Herrera, "Opposite metabolic response to fenofibrate treatment in pregnant and virgin rats," Journal of Lipid Research, vol. 43, no. 1, pp. 74-81, 2002.

[24] A. Soria, M. del Carmen González, H. Vidal, E. Herrera, and C. Bocos, "Triglyceridemia and peroxisome proliferator-activated receptor- $\alpha$ expression are not connected in fenofibrate-treated pregnant rats," Molecular and Cellular Biochemistry, vol. 273, no. 1-2, pp. 97-107, 2005.

[25] M. C. Sugden, G. K. Greenwood, N. D. Smith, and M. J. Holness, "Peroxisome proliferator-activated receptor- $\alpha$ activation during pregnancy attenuates glucose-stimulated insulin hypersecretion in vivo by increasing insulin sensitivity, without impairing pregnancy-induced increases in $\beta$-cell glucose sensing and responsiveness," Endocrinology, vol. 144, no. 1, pp. 146-153, 2003.

[26] M. J. Holness, G. K. Greenwood, N. D. Smith, and M. C. Sugden, "Peroxisome proliferator-activated receptor- $\alpha$ and glucocorticoids interactively regulate insulin secretion during pregnancy," Diabetes, vol. 55, no. 12, pp. 3501-3508, 2006.

[27] N. Martínez, V. White, M. Kurtz, R. Higa, E. Capobianco, and A. Jawerbaum, "Activation of the nuclear receptor PPAR $\alpha$ regulates lipid metabolism in foetal liver from diabetic rats: implications in diabetes-induced foetal overgrowth," Diabetes/Metabolism Research and Reviews, vol. 27, no. 1, pp. 3546, 2011.

[28] E. Capobianco, N. Martínez, R. Higa, V. White, and A. Jawerbaum, "The effects of maternal dietary treatments with natural PPAR ligands on lipid metabolism in fetuses from control and diabetic rats," Prostaglandins Leukotrienes and Essential Fatty Acids, vol. 79, no. 6, pp. 191-199, 2008.

[29] M. Gottlicher, E. Widmark, Q. Li, and J. A. Gustafsson, "Fatty acids activate a chimera of the clofibric acid-activated receptor and the glucocorticoid receptor," Proceedings of the National Academy of Sciences of the United States of America, vol. 89, no. 10, pp. 4653-4657, 1992.

[30] C. Bocos, M. Gottlicher, K. Gearing et al., "Fatty acid activation of peroxisome proliferator-activated receptor (PPAR)," Journal of Steroid Biochemistry and Molecular Biology, vol. 53, no. 1-6, pp. 467-473, 1995.

[31] M. I. Panadero, E. Herrera, and C. Bocos, "Different sensitivity of PPAR $\alpha$ gene expression to nutritional changes in liver of suckling and adult rats," Life Sciences, vol. 76, no. 9, pp. 10611072, 2005.

[32] S. S. T. Lee, T. Pineau, J. Drago et al., "Targeted disruption of the $\alpha$ isoform of the peroxisome proliferator- activated receptor gene in mice results in abolishment of the pleiotropic effects of peroxisome proliferators," Molecular and Cellular Biology, vol. 15, no. 6, pp. 3012-3022, 1995.

[33] H. N. Suh, H. T. Huong, C. H. Song, J. H. Lee, and H. J. Han, "Linoleic acid stimulates gluconeogenesis via $\mathrm{Ca}^{2+} / \mathrm{PLC}$, $\mathrm{CPLA}_{2}$, and PPAR pathways through GPR40 in primary 
cultured chicken hepatocytes," American Journal of Physiology, vol. 295, no. 6, pp. C1518-C1527, 2008.

[34] S. L. Lay, S. Krief, C. Farnier et al., "Cholesterol, a cell sizedependent signal that regulates glucose metabolism and gene expression in adipocytes," Journal of Biological Chemistry, vol. 276, no. 20, pp. 16904-16910, 2001.

[35] I. Inoue, S. Noji, M. Z. Shen, K. Takahashi, and S. Katayama, "The peroxisome proliferator-activated receptor $\alpha(\operatorname{PPAR} \alpha)$ regulates the plasma thiobarbituric acid-reactive substance (TBARS) level," Biochemical and Biophysical Research Communications, vol. 237, no. 3, pp. 606-610, 1997.

[36] Y. Kurihara, K. Egawa, S. Kunimoto, T. Takeuchi, and K. Nose, "Induction of p16/INK4a gene expression and cellular senescence by toyocamycin," Biological and Pharmaceutical Bulletin, vol. 25, no. 10, pp. 1272-1276, 2002.

[37] T. Aoyama, J. M. Peters, N. Iritani et al., "Altered constitutive expression of fatty acid-metabolizing enzymes in mice lacking the peroxisome proliferator-activated receptor $\alpha$ (PPAR $\alpha)$," Journal of Biological Chemistry, vol. 273, no. 10, pp. 56785684, 1998.

[38] J. D. Tugwood, I. Issemann, R. G. Anderson, K. R. Bundell, W. L. McPheat, and S. Green, "The mouse peroxisome proliferator activated receptor recognizes a response element in the 5' flanking sequence of the rat acyl CoA oxidase gene," The EMBO Journal, vol. 11, no. 2, pp. 433-439, 1992.

[39] J. P. Kehrer, S. S. Biswal, E. La et al., "Inhibition of peroxisomeproliferator-activated receptor (PPAR) $\alpha$ by MK886," Biochemical Journal, vol. 356, no. 3, pp. 899-906, 2001.

[40] T. R. Knight, S. Choudhuri, and C. D. Klaassen, "Induction of hepatic glutathione S-transferases in male mice by prototypes of various classes of microsomal enzyme inducers," Toxicological Sciences, vol. 106, no. 2, pp. 329-338, 2008.

[41] A. Balsalobre, F. Damiola, and U. Schibler, "A serum shock induces circadian gene expression in mammalian tissue culture cells," Cell, vol. 93, no. 6, pp. 929-937, 1998.

[42] L. Canaple, J. Rambaud, O. Dkhissi-Benyahya et al., "Reciprocal regulation of brain and muscle Arnt-like protein 1 and peroxisome proliferator-activated receptor $\alpha$ defines a novel positive feedback loop in the rodent liver circadian clock," Molecular Endocrinology, vol. 20, no. 8, pp. 1715-1727, 2006.

[43] K. Yamazaki, J. Kuromitsu, and I. Tanaka, "Microarray analysis of gene expression changes in mouse liver induced by peroxisome proliferator-activated receptor $\alpha$ agonists," Biochemical and Biophysical Research Communications, vol. 290, no. 3, pp. 1114-1122, 2002.

[44] J. S. Wong and S. S. Gill, "Gene expression changes induced in mouse liver by di(2-ethylhexyl) phthalate," Toxicology and Applied Pharmacology, vol. 185, no. 3, pp. 180-196, 2002.

[45] A. L. Fowden, J. Li, and A. J. Forhead, "Glucocorticoids and the preparation for life after birth: are there longterm consequences of the life insurance?" Proceedings of the Nutrition Society, vol. 57, no. 1, pp. 113-122, 1998.

[46] V. Zilberfarb, K. Siquier, A. D. Strosberg, and T. Issad, "Effect of dexamethasone on adipocyte differentiation markers and tumour necrosis factor- $\alpha$ expression in human PAZ6 cells," Diabetologia, vol. 44, no. 3, pp. 377-386, 2001.

[47] S. Kersten, J. Seydoux, J. M. Peters, F. J. Gonzalez, B. Desvergne, and W. Wahli, "Peroxisome proliferator-activated receptor $\alpha$ mediates the adaptive response to fasting," Journal of Clinical Investigation, vol. 103, no. 11, pp. 1489-1498, 1999.

[48] P. Lopez-Luna, J. Olea, and E. Herrera, "Effect of starvation on lipoprotein lipase activity in different tissues during gestation in the rat," Biochimica et Biophysica Acta, vol. 1215, no. 3, pp. 275-279, 1994.
[49] H. el Azzouzi, S. Leptidis, M. Bourajjaj et al., "Peroxisome proliferator-activated receptor (PPAR) gene profiling uncovers insulin-like growth factor-1 as a PPAR $\alpha$ target gene in cardioprotection," Journal of Biological Chemistry, vol. 286, no. 16, pp. 14598-14607, 2011.

[50] K. Karaya, S. Mori, H. Kimoto et al., "Regulation of Id2 expression by CCAAT/enhancer binding protein $\beta$," Nucleic Acids Research, vol. 33, no. 6, pp. 1924-1934, 2005.

[51] M. Prisco, F. Peruzzi, B. Belletti, and R. Baserga, "Regulation of Id gene expression by type 1 insulin-like growth factor: roles of STAT3 and the tyrosine 950 residue of the receptor," Molecular and Cellular Biology, vol. 21, no. 16, pp. 5447-5458, 2001.

[52] A. Zambon, P. Gervois, P. Pauletto, J.-C. Fruchart, and B. Staels, "Modulation of hepatic inflammatory risk markers of cardiovascular diseases by PPAR- $\alpha$ activators: clinical and experimental evidence," Arteriosclerosis, Thrombosis, and Vascular Biology, vol. 26, no. 5, pp. 977-986, 2006.

[53] A. Hermanowski-Vosatka, D. Gerhold, S. S. Mundt et al., "PPAR $\alpha$ agonists reduce $11 \beta$-hydroxysteroid dehydrogenase type 1 in the liver," Biochemical and Biophysical Research Communications, vol. 279, no. 2, pp. 330-336, 2000.

[54] J. C. Corton, E. S. Moreno, A. Merritt, C. Bocos, and R. C. Cattley, "Cloning genes responsive to a hepatocarcinogenic peroxisome proliferator chemical reveals novel targets of regulation," Cancer Letters, vol. 134, no. 1, pp. 61-71, 1998.

[55] P. R. Holden and J. D. Tugwood, "Peroxisome proliferatoractivated receptor alpha: role in rodent liver cancer and species differences," Journal of Molecular Endocrinology, vol. 22, no. 1, pp. 1-8, 1999. 


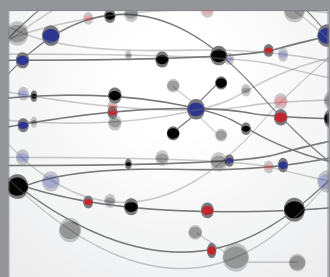

The Scientific World Journal
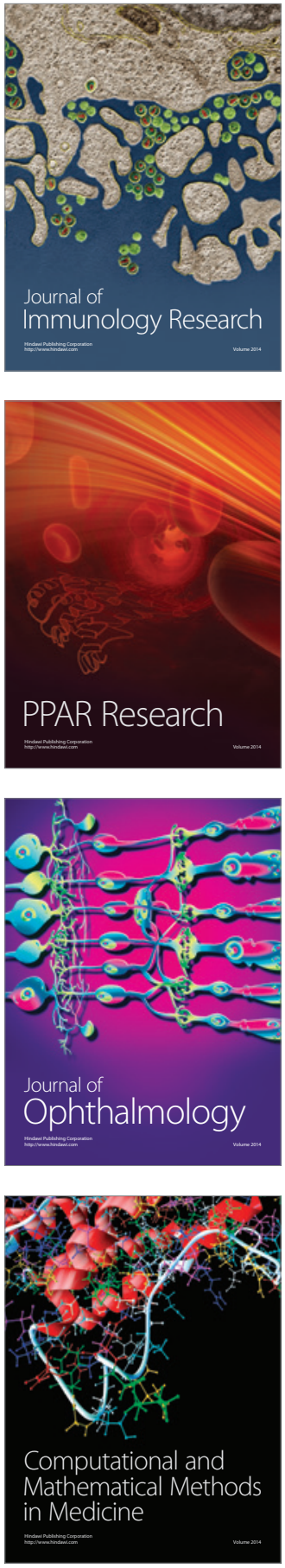

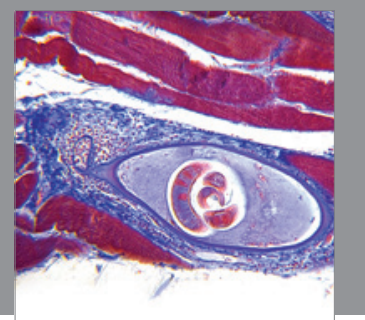

Gastroenterology

Research and Practice
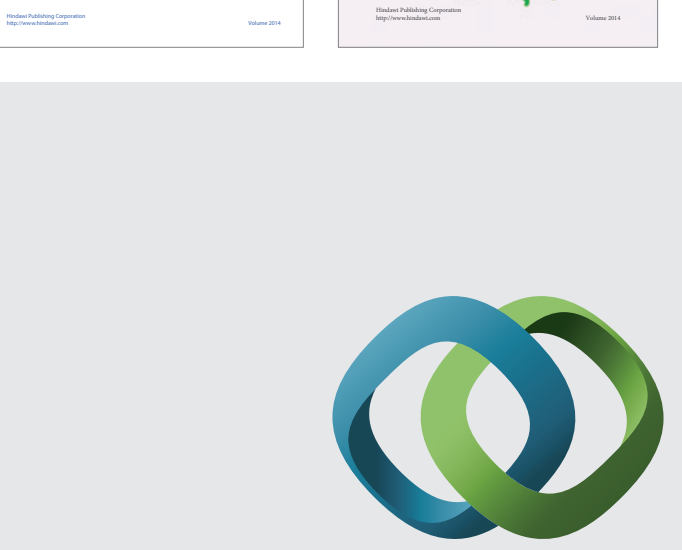

\section{Hindawi}

Submit your manuscripts at

http://www.hindawi.com
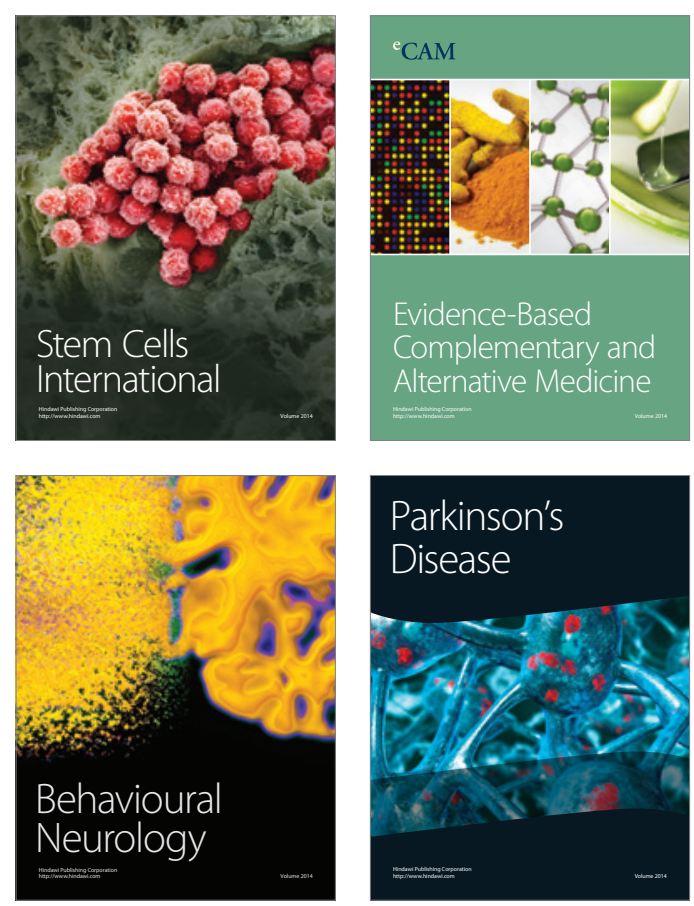

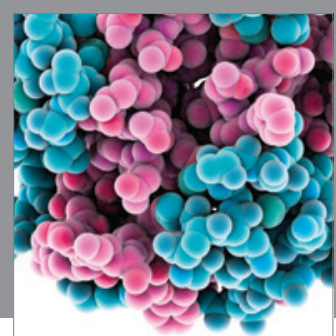

Journal of
Diabetes Research

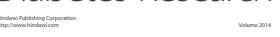

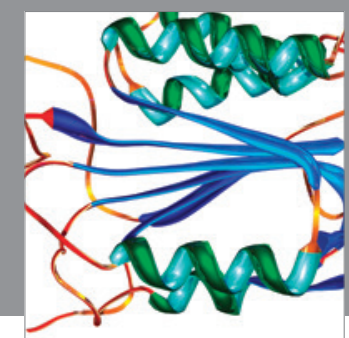

Disease Markers
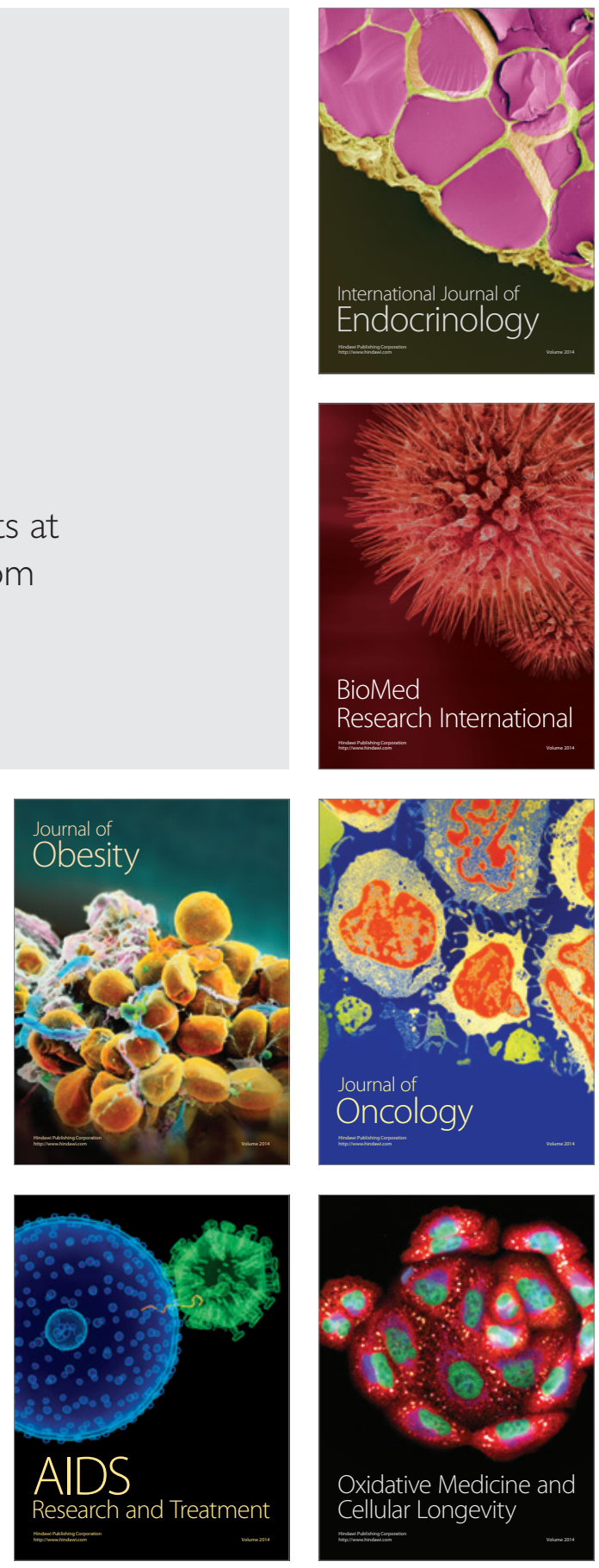